RESEARCH ARTICLE

\section{Murat Evimez ${ }^{1}$ \\ Nevgul Demir ${ }^{1}$ \\ Oguz Tekin ${ }^{1}$}

\begin{abstract}
${ }^{1}$ University of Health Sciences, Ankara Kecioren Health Research Center, Department of Family Medicine, Ankara, Turkey
\end{abstract}

\section{Corresponding Author:}

Nevgul Demir

Department of Family Medicine, Home Care Service Unit, University of Health Sciences, Ankara Kecioren Health Research Center, 06380, Ankara, Turkey mail: nevguldemir@yahoo.com Phone: +903123569000

Received: 02.01.2019 Acceptance: 09.03.2020 DOI: $10.18521 / \mathrm{ktd} .506502$

\section{Konuralp Medical Journal e-ISSN1309-3878 \\ konuralptipdergi@duzce.edu.tr konuralptipdergisi@gmail.com www.konuralptipdergi.duzce.edu.tr}

\section{The Challenges Facing In-Home Caregivers: An Analyses of the Results of a Survey Using a Validated Questionnaire ABSTRACT}

Objective: Even though there are reports indicating positive aspects of home-based caregiving of patients who are in need, there are also noteworthy concerns that this may lead to a significant load on such caregivers who are family members. The aim of our study is to investigate the attitudes of these caregivers against the challenges of life compared to a control group.

Methods: Fifty caregivers who took care of their patients at home and 50 persons who had no in-home care task were compared. A questionnaire, scoring in five separate fields named as Thoughts against the challenges of life (TAC), Perspective on life (PL), Problem solving ability (PSA), Targets and ideals (TI) and Social support (SS), was conducted. It is assumed that persons with higher scores do better against challenges of life.

Results: Seventy-six percent of Caregivers Group (CRG) were women and 58\% of them were housewives. PL scores of CRG were significantly lower, but the PSA scores of them were significantly higher compared to those of control group (CNG). Univariate analyses revealed that caregiving status, age and gender had no significant impact on any of the scores, but the duration of education had significantly affected the scores of PL. PL scores of subgroups educated 5 years or less were significantly lower in CRG compared to CNG group.

Conclusion: Care-giving seems to have a positive impact on PSA scores, but a negative one on PL scores. Education was the variable most widely effecting field scores, both in positive and in negative directions.

Key Words: Home-Based Patient Care, Caregivers, Mental Health of Caregivers, Attitudes of Caregivers.

\section{Evde Hasta Bakımı Yapan Kişilerin Karşılaştığı Zorluklar: Geçerli Bir Ölçek Aracılığıyla Elde Edilen Verilerin Analizi ÖZET}

Amaç: Bakıma muhtaç kişilerin kendi evlerinde bakımıyla ilgili olumlu bildirimler vardır; fakat evde bakımın aile üyesi olan bakıcılar üzerinde önemli bir yük oluşturabileceği konusunda kayda değer endişeler de vardır. Amacımız, bakıma muhtaç kişilere evlerinde bakım hizmeti veren hane halkından kişilerin, hayatın güçlüklerine karşı tutumlarını araştırmak ve bu tutumları bir kontrol gurubuyla karşılaş̧ırmaktır.

Gereç ve Yöntem: Hastalarına evlerinde bakım veren 50 bakıcı ve bakıcılık yapmayan 50 kişi karşılaştırılmıştır. Çalışmaya katılan kişilerin hayatın güçlüklerine karşı tutumları, daha önce geçerliliği gösterilmiş bir anket-ölçekle değerlendirildi. Bu anket-ölçekteki sorular, güçlüklere karşı düşünceler (GKD), hayata bakış $(\mathrm{HB})$, problem çözme (PÇ), hedef ve idealler (HI) ve sosyal destek (SD) olmak üzere beş ayrı alanda skorlar üretmektedir. Skorların yüksek olması olumlu olarak değerlendirilmektedir.

Bulgular: Bakıcı Gurubunun (BG) \%76'sı kadın ve \%58'i ev hanımlarından oluşuyordu; \%54'ü beş yıl veya daha az eğitim almıştı. Bakıcı Gurubunun HB skorları KG'ye göre anlamlı şekilde düşük, buna karşıllk PÇ skorları anlamlı şekilde daha yüksekti [Mann-

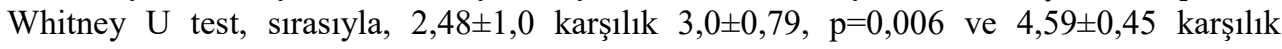
$4,28 \pm 0,69, \mathrm{p}=0,035]$. Univariate analiz sonuçları, hastabakıcilık durumu, yaş ve cinsiyetin, skorların hiçbiri üzerinde anlamlı etkide bulunmadığını gösterdi, fakat eğitim süresinin HB $[\mathrm{F}(1,95)=8,534, \mathrm{p}=0,004]$ ve $\mathrm{SD}[\mathrm{F}(1,95)=13,673, \mathrm{p}=0,001]$ skorların anlamlı şekilde etkilediği görüldü. Beş yıl ve daha az eğitim alan alt-guruplarda $\mathrm{HB}$ skorları BG'de, KG'ye göre anlamlı olarak daha düşüktü [(BG: $\mathrm{n}=27$, ort $\pm \mathrm{se}=2,22 \pm 0,20 ; \mathrm{KG}: \mathrm{n}=21$, ort $\pm \mathrm{se}=$ $2,90 \pm 0,15$, t-testi, $\mathrm{p}=0,009)]$.

Sonuç: Hastabakıcılığın PÇ üzerinde olumlu, fakat HB skorları üzerinde negatif etkileri olduğu görülüyor. Eğitimin, alan skorlarını, olumlu veya olumsuz yönde, en çok etkileyen değişken olduğu görüldü.

Anahtar Kelimeler: Evde Hasta Bakımı, Hastabakıcılar, Hastabakıcıların Zihinsel Sağlı̆̆ı, Hastabakıcıların Tutumları 


\section{INTRODUCTION}

An approach for the patients who are not able to handle with their daily life activities is taking care of such patients at their own homes. Home-Based Care (HBC) can be provided by their relatives (unpaid/paid) or professionals (paid). Whenever health parameters were taken into account, it is claimed that the HBC patients scored better than the others.

There are positive and/or negative impacts of HBC of chronically ill person to the caregivers and other family members. According to the data from the US, the families who are caregiving are giving out $10 \%$ of their house incomes for their chronically ill patients (1). Restriction of working options, neglection of the needs of other family members, limitation of time spent with other family members, social isolation and depression are reported to be some of the negative aspects of caregiving (2). First-hand caregivers are reported to be affected more than the others. According to the data from Turkey, caregivers mostly suffer from somatoform disorders.

On the other hand, it is also reported that caregivers might also be more self confident by the time (3). Preservation of family integrity is also recorded to be a positive aspect of HBC (4).

As it is possibly a stress-inducing activity, one of the factors determining caregiving to be a negative or a positive experience may be the attitude against stressors. Thoughts about the challenges of life, appraisal of life, problem solving abilities, individual ideals and targets and social supports are affecting the happiness and the capability of individuals to handle with difficulties (5).

The aim of our study is to assess the attitudes of in-home caregivers against the challenges of life by way of a valid and reliable scale and compare their attitudes with a group of patients who were not caregivers but visited our outpatient clinics.

\section{MATERIAL AND METHODS}

Participants: Fifty persons caregiving to their in-home patients registered to HBMC Unit of S.B.U. Keçiören Education and Research Hospital were included in Caregivers Group (CRG). Control Group (CNG) included 50 patients who were not caregivers but attended for several reasons to our outpatient clinic.

Inclusion Criteria: There were 67 registered patients in the HBMC Unit. All of caregivers who gave consent, were 18 years old or more and had no self-reported psychological problems were enrolled in the study (CRG). CNG group participants were selected if they gave conscent for the study, were aged 18 years old or more, and had no self-reportedpsychological problems.

They were all questioned face-to-face via Bursa-Attitude Against Challenges Questionnaire
(BAACQ). This questionnaire was including 26 questions.

Exclusion Criteria: Those who did not give informed consent or did not answer all the questions were excluded from the study.

Bursa-Attitude Against Challenges Questionnaire (BAACQ): This questionnaire is formed by Tekin et al. in 2009 to assess the attitudes of individuals against the challenges of life and the general Cronbach-alpha value of it is 0,810 . It includes five sub-fields: Thoughts Against the Challenges (TAC), Perspective on Life (PL), Problem Solving Ability (PSA), Targets and Ideals (TI) and Social Support (SS). It consists of 26 questions and can be answered by way of five points Likert Scale; it is translated into english $(6,7)$.

Statistics: Data were analysed by SPSS 21 software (IBM Corp. Released 2012. IBM SPSS Statistics for Windows, Version 21.0. Armonk, NY: IBM Corp). Data were given as numbers, ratios, percentages, mean \pm standard deviation (sd), mean \pm standard error (se), median (interquartil range), minimum-maximum values, where appropriate. General Linear Model Univariate Analysis Menu was used to analyse the effects of the variables on the BAACQ sub-field scores. The data were checked for test assumptions. To assess the effect of caregiving status on scores, the model including the caregiving status, gender, age and the duration of education was used. For the CRG scores, variables such as gender, age, duration of education, relationship status, age of the patient taken care of, the duration of in-home care were added to the model. For the CNG scores, variables such as age, gender and the duration of education were added to the model. To investigate the differences between two groups, Student's t and Mann-Whitney U (MWU) tests were used, where appropriate. Bonferoni correction was made when it was necessary. Kruskall-Wallis variance analysis was used to compare the difference between meanvalues of multiple groups. Spearman test was used when needed for the correlation analysis. Statistical significance level was estimated to be $\mathrm{p}<0.05$. Normality of the data were tested by Kolmogorov-Smirnov Test (whenever it was $\mathrm{p}>0.05$, it was accepted that data fit the normal distribution). Approval of S.B.U. Keçiören Education and Research Hospital's Ethics Committee is obtained (25.10.2017/1532) and the whole study processes are fulfilled in accordance with the Declaration of Helsinki.

\section{RESULTS}

Fifty caregivers and 50 patients as controls, 100 persons in total were included in the study. Their demographic data are summarized in Table 1. Participants in CRG and CNG were housewifes by 58 and $60 \%$, respectively. 
Table 1. Demographic data and BAACQ scores of the study population

\begin{tabular}{|c|c|c|c|}
\hline & CRG & $\mathrm{CNG}$ & $p$ \\
\hline Age $($ mean \pm sd $)$ & $52,0 \pm 10,5$ & $39,7 \pm 13,3$ & $0,0001^{\mathrm{a}}$ \\
\hline Gender (F/M; n, \%) & $38 / 12(76 / 24)$ & $41 / 9(82 / 18)$ & - \\
\hline Duration of education (years, mean \pm sd) & $8,0 \pm 4,2$ & $8,3 \pm 4,1$ & $0,7^{\mathrm{a}}$ \\
\hline $0-5$ years $(\mathrm{n}, \%)$ & $27(\% 54)$ & $21(\% 42)$ & - \\
\hline $6-8$ years $(n, \%)$ & $4(\% 8)$ & $9 \quad(\% 18)$ & - \\
\hline$>8$ years $(\mathrm{n}, \%)$ & $19(\% 38)$ & $20(\% 40)$ & - \\
\hline \multicolumn{4}{|l|}{ Graduation } \\
\hline No schooling $(\mathrm{n}, \%)$ & $2(\% 4)$ & $3(\% 6)$ & - \\
\hline primary $(\mathrm{n}, \%)$ & $25(\% 50)$ & $18(\% 36)$ & - \\
\hline secondary $(\mathrm{n}, \%)$ & $4(\% 8)$ & $9(\% 18)$ & - \\
\hline High school $(\mathrm{n}, \%)$ & $9(\% 18)$ & $12(\% 24)$ & - \\
\hline University $(\mathrm{n}, \%)$ & $10(\% 20)$ & $7(\% 14)$ & - \\
\hline Doctorate $(\mathrm{n}, \%)$ & - & $1(\% 2)$ & - \\
\hline \multicolumn{4}{|l|}{ Occupation $(\mathrm{n}, \%)$} \\
\hline Health & $1(\% 2)$ & $3(\% 6)$ & - \\
\hline Education & $6(\% 12)$ & $1(\% 2)$ & - \\
\hline Security & - & $2(\% 4)$ & - \\
\hline Technical & $3(\% 6)$ & $3(\% 6)$ & - \\
\hline Worker, white-collar & $9(\% 18)$ & $9(\% 18)$ & - \\
\hline Independent & $2(\% 4)$ & $2(\% 4)$ & - \\
\hline Housewife & $29(\% 58)$ & $30(\% 60)$ & - \\
\hline \multicolumn{4}{|l|}{ BAACQ Scores } \\
\hline TAC $($ mean \pm se $)$ & $4,02 \pm 0,57$ & $4,09 \pm 0,56$ & $0,675^{\mathrm{b}}$ \\
\hline $\mathrm{PL}($ mean $\pm \mathrm{se})$ & $2,48 \pm 1,0$ & $3,0 \pm 0,79$ & $0,006^{b}$ \\
\hline PSA (mean \pm se $)$ & $4,59 \pm 0,45$ & $4,28 \pm 0,69$ & $0,035^{\mathrm{b}}$ \\
\hline $\mathrm{TI}($ mean \pm se $)$ & $4,58 \pm 0,37$ & $4,60 \pm 0,35$ & $0,803^{\mathrm{b}}$ \\
\hline SS (mean \pm se $)$ & $3,47 \pm 0,98$ & $3,82 \pm 1,0$ & $0,059^{\mathrm{b}}$ \\
\hline \multicolumn{4}{|l|}{ Relationship status } \\
\hline Daughter-in-law (n, \%) & $12(\% 24)$ & - & - \\
\hline son $(\mathrm{n}, \%)$ & $9(\% 18)$ & - & - \\
\hline Spouse $(\mathrm{n}, \%)$ & $9(\% 18)$ & - & - \\
\hline daughter $(\mathrm{n}, \%)$ & $13(\% 26)$ & - & - \\
\hline sibling $(\mathrm{n}, \%)$ & $1(\% 2)$ & - & - \\
\hline other $(\mathrm{n}, \%)$ & $6(\% 12)$ & - & - \\
\hline
\end{tabular}

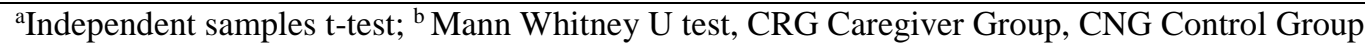

The median age of patients who were being taken care of was 80,5 (35-96) years; 38 were women and 12 were men. The median age of men was 84,5 (60-96); the median age of women was 77,5 (35-96). The most often diagnosed illnesses among them were respectively cerebrovascular accident (\%44), Alzheimer Disease (\%12) and senility (\%12). The median duration of in-home care was 5 (17), with minimum 0,2 years, maximum 34 years.

BAACQ Scores: PL and PSA scores among two groups were found to be statistically significantly different. The difference between SS scores was statistically significant on the limit, but differences among TAC and TI scores were not significant (Table 1). An individual sum of scores were obtained for every participant by way of summing their TAC, PL, TI and PSA scores. The Mean $(95 \% \mathrm{CI})$ total scores for CRG

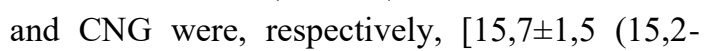
$16,1)$ and $16,0 \pm 1,4 \quad(15,6-16,4)$ MWU test $\mathrm{p}>0.05]$. According to the univariate analysis results, TAC and PSA scores have not been affected by any variable. PL and SS scores were the most affected scores by the variables (Table 5)

Effects of variables on BAACQ scores (both groups) Caregiving status: PL scores were lower and PSA scores were higher among CRG group compared to those among $\mathrm{CNG}$ group (Table 1). According to the univariate analysis results done without dividing into subgroups, caregiving status did not affect significantly any of the field scores of BAACQ (Table 4). On the other hand, when the participants were divided into 3 
Table 2. BACCQ scores of Caregivers group (CRG) according to their relationship to the care-given person, educational and occupational status

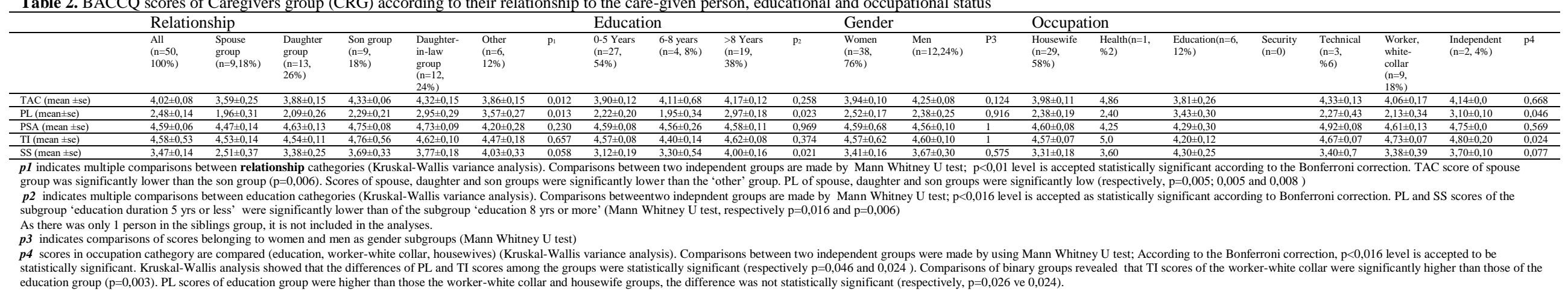

Table 3. BAACQ scores of control group (CNG) according to their gender, educational and occupational status

\begin{tabular}{|c|c|c|c|c|c|c|c|c|c|c|c|c|c|c|c|c|}
\hline & $\begin{array}{l}\text { All }(\mathrm{n}=50, \\
100 \%)\end{array}$ & $\begin{array}{l}\text { Women } \\
(\mathrm{n}=41,82 \%)\end{array}$ & $\begin{array}{l}\text { Men }(\mathrm{n}=9, \\
18 \%)\end{array}$ & p1 & $\begin{array}{l}0-5 \text { Years } \\
\text { education }(\mathrm{n}=21 \text {, } \\
42 \%)\end{array}$ & $\begin{array}{l}\text { 6-8 Years } \\
\text { education } \\
(\mathrm{n}=9,18 \%) \\
\end{array}$ & $\begin{array}{l}>8 \text { Years education } \\
(\mathrm{n}=20,40 \%)\end{array}$ & $\mathrm{p} 2$ & $\begin{array}{l}\text { Housewife } \\
(\mathrm{n}=30, \\
60 \%)\end{array}$ & $\begin{array}{l}\begin{array}{l}\text { Health } \\
(\mathrm{n}=3,6 \%)\end{array}\end{array}$ & $\begin{array}{l}\text { Education } \\
(\mathrm{n}=1,2 \%)\end{array}$ & $\begin{array}{l}\begin{array}{l}\text { Security } \\
(\mathrm{n}=2,4 \%)\end{array}\end{array}$ & $\begin{array}{l}\text { Technical(n=3, } \\
6 \%)\end{array}$ & $\begin{array}{l}\text { Worker, white } \\
\text { collar }(\mathrm{n}=9,18 \%)\end{array}$ & $\begin{array}{l}\text { Independent( } \mathrm{n}=2 \text {, } \\
4 \%)\end{array}$ & p3 \\
\hline TAC (mean $\pm \mathrm{se})$ & $4,09 \pm 0,08$ & $4,07 \pm 0,08$ & $4,16 \pm 0,22$ & 0,728 & $4,18 \pm 0,11$ & $4,25 \pm 0,20$ & $3,91 \pm 0,13$ & 0,175 & $4,09 \pm 0,10$ & $3,86 \pm 0,08$ & 4,43 & $3,29 \pm 0,29$ & $4,52 \pm 0,13$ & $4,10 \pm 0,25$ & $4,36 \pm 0,07$ & 0,961 \\
\hline $\mathrm{PL}(\mathrm{m}$ man $\pm \mathrm{se})$ & $3,00 \pm 0,11$ & $3,07 \pm 0,13$ & $2,71 \pm 0,22$ & 0,240 & $2,90 \pm 0,15$ & $2,49 \pm 0,20$ & $3,34 \pm 0,19$ & $0,027^{*}$ & $3,0 \pm 0,15$ & $3,60 \pm 0,50$ & 3,60 & $2,20 \pm 0,60$ & $2,93 \pm 0,27$ & $3,02 \pm 0,28$ & $2,70 \pm 0,50$ & 0,987 \\
\hline PSA (mean $\pm \mathrm{se}$ ) & $4,28 \pm 0,10$ & $4,29 \pm 0,11$ & $4,22 \pm 0,21$ & 0,673 & $4,39 \pm 0,12$ & $4,28 \pm 0,32$ & $4,16 \pm 0,16$ & 0,552 & $4,40 \pm 0,12$ & $4,17 \pm 0,33$ & 3,50 & $3,75 \pm 0,50$ & $4,50 \pm 0,29$ & $4,06 \pm 0,29$ & $4,25 \pm 0,25$ & 0,228 \\
\hline $\mathrm{TI}($ mean $\pm \mathrm{se})$ & $\begin{array}{l}4,2000,10 \\
4,60 \pm 0,05 \\
\end{array}$ & $\begin{array}{l}4,25 \pm 0,11 \\
4,59 \pm 0,06 \\
\end{array}$ & $\begin{array}{l}4,2 \pm 0,21 \\
4,67 \pm 0,11\end{array}$ & 0,534 & $4,70 \pm 0,07$ & $4,67 \pm 0,11$ & $4,47 \pm 0,08$ & 0,128 & $4,66 \pm 0,06$ & $4,40 \pm 0,23$ & 4,20 & $4,40 \pm 0,0$ & $4,60 \pm 0,31$ & $4,49 \pm 0,14$ & $4,90 \pm 0,10$ & 0,312 \\
\hline $\mathrm{SS}(\mathrm{mean} \pm \mathrm{se})$ & $\begin{array}{l}4,0 \pm 0,03 \\
3,82 \pm 0,15\end{array}$ & $\begin{array}{l}4,3,85 \pm 0,00 \\
3,85 \pm 0,16\end{array}$ & $\begin{array}{l}3,0,670,11 \\
3,67 \pm 0,33\end{array}$ & $0,0,518$ & $3,55 \pm 0,26$ & $3,64 \pm 0,26$ & $4,17 \pm 0,19$ & 0,213 & $3,73 \pm 0,20$ & $4,40 \pm 0,40$ & 4,60 & $2,80 \pm 1$ & $4,0 \pm 0,53$ & $3,91 \pm 0,32$ & $4,20 \pm 0,80$ & 0,731 \\
\hline
\end{tabular}
*

$p 2$ Scores of education cathegories have been compared (Kruskal-Wallis variance analysis). Binary subgroup comparisons showed that PL scores of the 'education 8 yrs ore more subgroup' were significantly higher than those of the 'education 6-8 yrs' subgroup (Mann Whitney U test,

$\mathrm{p}=0,008 ;$;
S Scores of housewifes and worker-white collar groups have been compared by using Mann Whitney $\mathrm{U}$ test. As there were very few cases, no comparion has been made among other groups. 
subgroups according to their duration of education $(0-5,6-8,>8$ years $)$ and analysed (caregiving status, age and gender were added to the model), the effect of caregiving status on PL scores in 0-5 years group found to be statistically significant on the limit $(F(1,44)=3,633$, $\mathrm{p}=0,063)$. When binary group comparisons were made, PL scores of CRG and CNG 0-5 years subgroups were found to be significantly different (CRG: $\mathrm{N}=27$, mean $\pm \mathrm{sd}=2,22 \pm 1$; $\mathrm{CNG}$ : $\mathrm{N}=21$, mean $\pm \mathrm{sd}=2,9 \pm 0,68$; Mann Whitney $\mathrm{U}$ test, $\mathrm{p}=0,009$ ).

Table 4. Effect of caregiving status on BAACQ scores according to the univariate analysis

\begin{tabular}{llllll}
\hline & Type III Sum of Squares & df & Mean Square & F & $\mathrm{p}$ \\
\hline TAC & 0,417 & 1 & 0,417 & 1,216 & 0,258 \\
\hline PL & 1,230 & 1 & 1,230 & 1,751 & 0,189 \\
\hline PSA & 0,603 & 1 & 0,603 & 1,787 & 0,184 \\
\hline TI & 0,092 & 1 & 0,092 & 0,709 & 0,402 \\
\hline SS & 0,759 & 1 & 0,759 & 0,915 & 0,341 \\
\hline Error & & 95 & & & \\
\hline
\end{tabular}

TAC thoughts against challenges, PL perspective on life, TI targets and ideals, PSA problem solving ability, SS Social Support

Educational status: When two groups are analysed entirely, a positive linear correlation has been detected between the PL, SS scores and the duration of education (Spearman's rho test, respectively, $\mathrm{r}=0,333, \mathrm{p}=0,001$ ve $\mathrm{r}=0,391, \mathrm{p}=$ 0,0001). A negative correlation with TAC scores and positive correlations with PSA and TI scores were observed, both of which were statistically non-significant. Likewise, by an univariate analysis model in which caregiving status, age, gender and the duration of education were included, it is estimated that the duration of education significantly affected the PL $[F(1,95)=8,534, \quad p=0,004]$ and SS scores $[\mathrm{F}(1,95)=13,673, \mathrm{p}=0,001]$, but had no significant effect on TAC $[\mathrm{F}(1,95)=0,750$, $\mathrm{p}=0,389]$, PSA $[\mathrm{F}(1,95)=0,751, \mathrm{p}=0,388]$ and $\mathrm{TI}$ $[\mathrm{F}(1,95)=0,746, \mathrm{p}=0,390]$ scores. The PL score of the CRG education subgroup ' 5 years or less' was significantly lower than that of $\mathrm{CNG}$ counterpart [(CRG: $n=27$, mean \pm se $=2,22 \pm 0,20$; CNG: $\mathrm{n}=21, \quad$ mean $\pm \mathrm{se}=2,90 \pm 0,15$, t-test, $\mathrm{p}=0,009)]$.

Table 5. Effects of the variables on the sub-field scores

\begin{tabular}{|c|c|c|c|c|c|c|c|c|c|c|c|c|c|c|c|}
\hline & All & & & & & $\mathrm{CRG}$ & & & & & $\mathrm{CNG}$ & & & & \\
\hline & TAC & PL & PSA & TI & SS & TAC & $\mathrm{PL}$ & PSA & TI & $\mathrm{SS}$ & TAC & PL & PSA & TI & SS \\
\hline Caregiving & - & - & - & - & - & & & & & & & & & & \\
\hline Gender & - & - & - & - & - & - & + & - & - & - & - & - & - & - & - \\
\hline Age & - & - & - & - & - & - & - & - & - & - & - & - & - & - & - \\
\hline $\begin{array}{l}\text { Duration of } \\
\text { education }\end{array}$ & - & + & - & - & + & - & + & - & - & + & - & $\begin{array}{l}+/- \\
*\end{array}$ & - & + & - \\
\hline Relationship & & & & & & - & + & $+/-*$ & - & + & & & & & \\
\hline $\begin{array}{l}\text { Age of the } \\
\text { patient }\end{array}$ & & & & & & - & - & - & - & - & & & & & \\
\hline $\begin{array}{l}\text { Duration of } \\
\text { in-home } \\
\text { care }\end{array}$ & & & & & & - & - & - & - & - & & & & & \\
\hline
\end{tabular}

Results of univariate analysis. + indicates the statistical significance in the model , - indicates the non-significant variables.

Statistical expressions are given in the text, where appropriate

*Borderline significance

Gender, age and occupation: When all the subjects were taken as a whole, negative linear correlations between age and PL scores and also between age and SS scores were detected (Spearman's rho test, respectively, $r=$ 456, $\mathrm{p}=0,0001$ and $\mathrm{r}=-0,337, \mathrm{p}=0,001)$. Positive but unsignificant correlations were detected between age and TAC, PSA and HI scores (datas are not shown). But univariate analysis revealed that the effects of age variable on BAACQ scores were not statistically significant. Likewise, gender variable in this model had also no significant effect on the scores (datas are not shown). Only the SS scores of women in 6-8 years education subgroup were higher than those of men and the difference among them had a limited significance (men: $\mathrm{n}=5$, mean $\pm \mathrm{sd}=2$, $92 \pm 0,66$; women: $\mathrm{n}=8$, mean $\pm \mathrm{sd}=3,93 \pm 0,076$; Mann Whitney $U$ test, $p=0,045)$. The effect of gender on SS score has also been shown to have limited significance by way of univariate analysis $[\mathrm{F}(1,9)=5,347, \mathrm{p}=0,046]$. When two 
groups were assessed together, BAACQ score differences among occupation groups were not statistically significant (Kruskal-Wallis test, $\mathrm{p}>0.05$ ).

Effects of variables on BAACQ scores of Caregiver Group

Gender: BAACQ scores did not show a significant difference in terms of gender groups (Table 2). Univariate analysis showed that gender status had a limited effect on PL scores $[F(1,39)=4,108, p=0,05)]$; Gender status had no significant effect on other fields' scores.

Education: A significantly positive correlation between the duration of education and PL, SS scores has been estimated (Spearman rho, respectively, $r=0,426, p=0,002$ ve $r=0,678$, $\mathrm{p}=0,0001)$. PL and SS scores of more educated ( 8 years or more) subgroup were significantly higher than those of less educated (5 years and) subgroup (Table 2). Likewise, univariate analyses have shown that the education status had a significant effect on PL $[F(1,39)=10,524$, $\mathrm{p}=0,002)]$ and $\mathrm{SS}[\mathrm{F}(1,39)=19,938, \mathrm{p}=0,001)]$ scores.

Relationship status: TAC scores of spouse group were lower than those of son group; PL scores of spouse, son and daughter were lower than the other groups (Table 2). Univariate analyses have shown that relationship status significantly affected the PL $[\mathrm{F}(5,39)=2,655, \quad \mathrm{p}=0,037)] \quad$ and $\mathrm{SS}$ $[\mathrm{F}(5,39)=2,866, \mathrm{p}=0,027)]$ scores. The relation between the relationship status and other field scores were as follows: PSA $[\mathrm{F}(5,39)=2,429$, $\mathrm{p}=0,052)]$, TI $[\mathrm{F}(5,39)=1,505, \mathrm{p}=0,211)]$ and TAC $[\mathrm{F}(5,39)=2,014, \mathrm{p}=0,098)]$.

Age: A correlation of high magnitude has been observed between age and PL scores (Spearman rho, $\mathrm{r}=0,466, \mathrm{p}=0,001$ ), but according to the univariate analysis, age was not an effective factor on scores.

Age of the care-given person and the duration of in-home care

Univariate analysis showed no significant effect of these variables on BAACQ scores. A significant correlation has been detected between the age of the patient and TAC scores (Spearman rho, $r=0,313, p=0,027)$. No significant effect of these variableson BAACQ scores have been detected.

Occupation: There were differences between education, worker-white collar and housewife groups in terms of PL and TI scores (Table 2).

\section{Effects of variables on BAACQ scores of Control Group \\ Gender: There were no significant} differences between BAACQ scores of men and women. Univariate analysis showed that gender has no significant effect on any of the field scores (no data are shown).
Education: A significantly positive correlation between the duration of education and PL (Spearman rho, r= 324, $\mathrm{p}=0,022$ ), TI (Spearman rho, $r=-286, p=0,044)$ and SS scores (Spearman rho, $r=354, p=0,012$ ) has been estimated. Multiple group comparisons showed that PL scores were significantly different among d education subgroups (Table 3). Univariate analysis showed that education status is significantly affecting TI scores $[\mathrm{F}(1,46)=6,468$, $\mathrm{p}=0,014)]$, it has a limited significance about affecting PL scores $(\mathrm{p}=0,07)$ and has no significant effect on other field scores.

Age: A statistically significant correlation is detected between age and PL (Spearman rho, $r=-297, p=0,037$ ), and SS (Spirman rho, $r=-343$, $\mathrm{p}=0,015)$ scores. Univariate analyses showed that age variable has no significant effect on field scores.

Occupation: There were no significant differences between BAACQ scores in terms of occupational groups (Table 3).

\section{DISCUSSION}

Main findings of our study can be summarized as follows: Firstly, PL scores of CRG were lower but PSA scores were higher than those of CNG. IUnivariate analysis results showed that caregiving status has no significant effect on any of the field scores. It is found that only in CRG's 0-5 years education subgroup, caregiving status might have a limited significant effect on PL scores. Secondly, various magnitude of relationships between educational status and scores are detected. It is observed that not all scores become higher as the duration of education becomes longer; instead, some scores were found higher in lower education group. As the third, the mean scores (except TAC) of spouse subgroup of CRG were lower compared to those of daughter, son and daughter-in-law subgroups (Table 1,2,3,4).

Other results obtained can be summarized as follows: The majority of participants were low-educated and housewives in both groups. The high number of daughter-in-law in CRG was a striking finding; If we sort the mean field scores from high to low, they ranked first or second among spouse, daughter or son subgroups. Gender had no evident effect on scores; it had a limited effect on some subgroups. Positive or negative correlations have been estimated between age and some scores but univariate analyse showed no significant correlation. Occupational status had an affect on scores in CRG but no effect was shown in CNG. A positive correlation has been found between the age of the care-given person and TAC scores of caregivers. As expected, the majority patients who were taken care of had central nervous system illnesses. 
There are many studies suggesting that caregiving has negative impacts on individuals. According to these studies, lack of freedom, limitation of personal life, negative impacts on family life and social life, stress, anxiety, feelings of insufficiency are frequently detected among caregivers (8-10). But there are also studies suggesting some positive impacts. It is also shown that caregivers may enjoy experience, satisfaction, benefits, personal development, award and feeling of being useful (11). According to a study done by Kalınkara et al., despite the problems they had, $84,7 \%$ of caregivers were content with their status as caregivers (12). BAACQ scores, in our study, were not significantly affected in negative direction by caregiving status, which might suggest some positive aspects of care-giving status.

One of our interesting findings is that PSA scores were higher in CRG group. Correlations between PSA scores and age or duration of education were not statistically significant. So, it can be speculated that being constantly busy in a challenging situation might be helping to improve problem solving abilities.

CRG PL scores were lower compared to those of CNG; as it was shown in subgroup analyses, this could be because of caregiving status, but also because of differences of age and educational status among the groups.

In our study, coherent with the results of some previous studies, the majority of caregivers were spouses or children (12-14). Coherent with those of some of the previous studies, our findings could be interpreted as follows: the sociocultural dynamics of Turkish society define mainly women as caregivers in the families. It is thought that this might be increasing the responsibilities of women in the family (15). Our study finding was also coherent with the previous studies in which the average age of caregivers in the Turkish society were estimated to be around 50 (16-18). In our study, the average age of the caregivers was 52 .

The average duration of education of caregivers in our study was 8 years; they were mainly graduated from primary school. This finding was also coherent with those of previous studies $(12,17,19)$. In our study, as mentioned also in previous studies, in-home care patients were mainly suffering from neurological disorders (20-22).

As it was repetitively mentioned in previous studies, caregivers in our study were also mainly housewives $(12,23,24)$. It is well known that caregiving a patient at home has negative impacts on the family income and it makes it difficult for the caregiver to find a job with a regular income (1). As housewives do not take part in labor market, negative impact of their caregiving may not be evident. Instead, payments of social security to some of the caregivers may have a rise in family income.

Individuals who have a positive perspective on life are defined to be able to face the challenges of life, self-confident, content, realistic with achieveable targets and more tolerant in their relationships (25). In our study, duration of education had a significant effect on PL scores. When CRG and CNG were compared, PL scores of 0-5 years education subgroup of $\mathrm{CNG}$ were significantly lower than that of $\mathrm{CNG}$ counterpart. No similar finding has been found in literature. A relationship was detected also between the duration of education and SS scores. 6-8 years education subgroup of CRG had lower SS scores. No clarification for this finding could be made. We need additional data to clarify the effect of duration of education on PL and SS scores. It was also striking to see that longer duration of education was related with lower scores in some fields and we also have no clarification for this relation. Education is expected to strengthen a person against challenges of life, but we observed quite different situation in our study. It might be speculated that the defects of education systems or the socioeconomical changes occured by longer education might lead to negative personal attitudes. BAACQ scores of caregivers were differing according to their relationship status with the patients. TAC, PL and SS scores of spouses were lower than those of other relatives. No specific inquiry has been made about those lower scores of spouses but their being older than other relatives and their being also in need for care could lead lower BAACQ scores. In another study done before, spouses were mentioned to feel more burden of care (26).

The main limitation of our study was that there were some differences among the groups in terms of some variables such as age, educational status, etc.

\section{Conclusions}

In conclusion, care-giving seems to have a positive impact on PSA scores, but a negative one on PL scores of BAACQ. Education was the variable most widely effecting field scores, both in positive and in negative directions. Caregiving housewifes with the education level of five years or lower have lower PL scores, which might deserve a special attention for their psychological health.

\section{REFERENCES}

1. National Alliance For Caregiving; AARP. Caregiving in the U.S.: Executive Summary.

Bethesda, Md.: National Alliance For Caregiving. 2009. https://doi.org/10.26419/res.00062.002. 
2. Mc Corkle R, Grant M, Frank S. M et al. Cancer Nursing: A Comprehensive Textbook. W.B. Saunders Company, Philadelpia. 1996.

3. Uğur Ö. Onkoloji Hastasına Evde Bakım Verenlerin Bakım Yükünün Belirlenmesi (tez). (Determination of the burden of caregivers on oncology patients, thesis). İzmir: Ege Üniversitesi Sağlı Bilimleri Enstitüsü. 2006.

4. Öztop H, Şener A, Güven S. Evde Bakımın Yaşlı ve Aile Açısından Olumlu ve Olumsuz Yönleri. (Advantages and disadvantages of home care in the aspect of elderly and family).Yaslı Sorunları Araştırma Dergisi 2008;(1): 39-49. http://dergipark.gov.tr/download/article-file/203238

5. Tunks E, Bellissimo A. Behavioral Medicine: Concepts and Procedures. Stress, life events, and coping. New York: Pergamon; 1991.

6. Tekin O, Göktaş O, Cebeci S. Yaşamın Güçlüklerine Karşı Tutumların Değerlendirilmesi - Bursa'da 298 Kişi Üzerinde Pilot Bir Çalışma. Yeni Tıp Dergisi 2009;26:79-84.

7. Goktas O, Tekin O, Sencan I. Attitudes to the challenges of life among different occupation groups. Turk J Med Sci. 2011;41(6):1051-7. doi:10.3906/sag-1009-1094.

8. Stoltz, P, Uden, G, Willman A. Support for Family Carers Who Care for an Elderly Person at Home - a Systematic Literature Review. Scandinavian Journal of Caring Sciences. 2004; 18(2),111-9. https://doi.org/10.1111/j.1471-6712.2004.00269.x

9. Erdem M. Yaşlıya Bakım Verme. (Care for the elderly). Anadolu Hemşirelik ve Sağlık Bilimleri Dergisi. 2005; 8(3),101-6. http://dergipark.gov.tr/ataunihem/issue/2631/33859

10. Özçakar N, Kartal M, Dirik G, et al.Burnout and relevant factors in nursing staff: What Affects the Staff Working in an Elderly Nursing Home? Turkish Journal of Geriatrics. 2012;15(3),266-72. http://dergipark.gov.tr/download/article-file/340486

11. Hanyok L A, Finucane T, Carrese J, et al. Potential Caregivers for Homebound Elderly: More Numerous Than Supposed? Journal of Family Practice. 2009;58 (7), E1-6.

12. Kalınkara V, Kalaycı I. Yaşlıya Evde Bakım Hizmeti Veren Bireylerde Yaşam Doyumu, Bakım Yükü ve Tükenmişlik. (Life satisfaction, care burden and burnout of the individuals who have a caregiver service to the elderly at home).Yaşlı Sorunları Araştırma Dergisi (YSAD). 2017;10(2),19-39. http://dergipark.gov.tr/yasad

13. Arpacı F. Yaşlıya Bakan Kadınların Bakım Yüklerinin İncelenmesi. (A study into caregiving burden of women caring of the elderly). Yaşlı Sorunları Araştırma Dergisi (YSAD) 2009; (1),61-72. http://dergipark.gov.tr/download/article-file/203227

14. Altın M. Alzheimer Tipi Demans Hastalarına Bakım Verenlerde Tükenmişlik ve Anksiyete (tez). İstanbul: Haydarpaşa Eğitim ve Araştırma Hastanesi Psikiyatri Kliniği. 2006.

15. Adak N. Yaşlıların Gayri Resmi Bakıcıları: Kadınlar. (Informal Caregivers of the Elderly: Women). Aile ve Toplum. 2003; (2),1-9. http://dergipark.gov.tr/download/article-file/198175

16. Akyar İ. Alzheimer Hastalarına Bakım Verenlerin Yaşadıkları Güçlükler (tez). (Strains of Caregivers of Alzheimer Patients, thesis). Ankara: Hacettepe Üniversitesi Sağlık Bilimleri Enstitüsü. 2006.

17. Çetinkaya F. Demanslı Hastaya Bakım Verenlerin Bakım Yükünün İncelenmesi (tez). Investigation of Care Burden in Dementia Patient Caregiver, thesis). İzmir: Ege Üniversitesi Sağlık Bilimleri Enstitüsü. 2008.

18. Küçükgüçlü Ö. Bakım verenlerin Yükü Envanteri"nin Türk Toplumu İçin Geçerlik ve Güvenirliğinin İncelenmesi (tez). İzmir: Ege Üniversitesi Sağlı Bilimleri Enstitüsü. 2004. http://hdl.handle.net/11454/1536

19. Dağdeviren T S. Evde Sağlık Hizmeti Alan Hastaların Bakım Veren Yakınlarında Bakım Yükünün Değerlendirilmesi (tez). Ankara: Sağlı Bilimleri Üniversitesi Keçiören Eğitim ve Araştırma Hastanesi. 2017.

20. Turk Tabipler Birliği Yayınları. (Turkish Medical Association). Evde Bakım Hizmetleri İle İlgili Sağlık Emek ve Meslek Örgütlerinin Görüş ve Yaklaşımları. 2016. https://www.ttb.org.tr/kutuphane/evdebakim.pdf

21. Cayır Y, Avşar Ü Z, Avşar Ü, et al. Evde Sağlık Hizmetleri Alan Hastaların Özellikleri ve Bakım Verenlerin Beklentileri. (Characteristics of Patients Who Receive Home Health Services and Expectations of Caregivers). $\quad$ Konuralp $\quad$ Tip $\quad$ Dergisi. http://www.konuralptipdergi.duzce.edu.tr/Sayfa/2520/2013-sayi--3

22. Deniz S, Çeldir Emre J, Özdemir Ö. Evde Bakım Hizmetlerinin Takip Ettiği Hastalardaki Akciğer Enfeksiyon Sıklığı. (Frequency of Pulmonary Infection in Patients Followed by Home Care Services). Smyrna T1p Dergisi. 2015; 1: 35-9.

23. Boyoğlu R, Oktay S. Hastane Destekli Evde Bakım Hizmetleri ve Sunumu (Hospital-Supported Home Care Services and Presentation), 1.O.F.N.H. Y.0 Hcmşirclik Dcrgisi, 2002;1(49), 99-118. http://dergipark.gov.tr/download/article-file/95266

24. Akça Kılıç N, Taşçı S. 65 Yaş Üstü Bireylere Bakım Verenlerin Yaşadıkları Sorunların Belirlenmesi. (Determination of the Problems Encountered by Those Providing Care for Elderly Above 65 Years Old). Sağlık Bilimleri Dergisi. 2005; 14(ek sayı):30-6. 
25. Kutlu M, Balcı S, Yılmaz, M. İletişim Beceri Eğitiminin Öğrencilerin Kendini Ayarlama ve İyimserlik Düzeylerine Etkisi. XIII. Ulusal Eğitim Bilimleri Kurultayı. Malatya: İnönü Üniversitesi Eğitim Fakültesi. 2004.

26. Or R. Yaşlıya Bakım Veren Aile Bireylerinin Bakım Verme Yükü Ve Bakım Verenin İyilik Hali. (Caregiving Burden And Well-Being Of Family Caregivers Of Elderly Persons, thesis) Denizli: Pamukkale Üniversitesi Sağlık Bilimleri Enstitüsü. 2013. 